\title{
Growth and mycorrhizal colonization of maize plants treated with aqueous extracts from nonmycorrhizal weeds
}

\author{
Karla Andréia de Melo(1) and Rosilaine Carrenho(2)
}

\begin{abstract}
(1)Universidade Estadual de Maringá (UEM), Programa de Pós-Graduação em Biologia Comparada, Avenida Colombo, no 5.790, CEP 87020-900 Maringá, PR, Brazil. E-mail: prof.karlamelo@gmail.com (2)UEM, Departamento de Biologia, Avenida Colombo, no 5.790, CEP 87020-900 Maringá, PR, Brazil. E-mail: rcarrenho@uol.com.br
\end{abstract}

\begin{abstract}
The objective of this work was to evaluate the influence of aqueous extracts of nonmycorrhizal weedy species on dry matter accumulation and assimilate partitioning of maize plants, with or without Cetraspora pellucida inoculation. The experiment was carried out in pots, in a completely randomized design, in a $5 \times 2$ factorial arrangement consisting of four plant extracts (purple nutsedge, guinea-hen weed, slender amaranth, and knotweed), a control irrigated with water, and two conditions (mycorrhizal and nonmycorrhizal maize plants), with four replicates of each treatment. Plants were irrigated with aqueous extracts diluted at 15\%. Root colonization (RC), shoot dry matter (SDM), root dry matter (RDM), and RDM/ SDM were evaluated. Root colonization was not influenced by the extracts, and ranged from 41.5 to $65.2 \%$. Shoot dry matter of mycorrhizal (AM) and nonmycorrhizal (NM) plants was not influenced by the extracts; however RDM showed varying responses. Mycorrhization favored the production of RDM, and increased plant sensitiveness to the extracts. Guinea-hen weed extract increased RDM of AM plants, while the other extracts inhibited it. In NM plants, the production of RDM was benefited by slender amaranth extract, to the detriment of SDM. Mycorrhizal and nonmycorrhizal maize plants respond differently to aqueous extracts of nonmycorrhizal weeds.
\end{abstract}

Index terms: Zea mays, Amaranthus viridis, Cyperus rotundus, Petiveria alliacea, Polygonum ferrugineum, allelopathy.

\section{Crescimento e colonização micorrízica de plantas de milho tratadas com extratos de plantas infestantes não micorrízicas}

\begin{abstract}
Resumo - O objetivo deste trabalho foi avaliar a influência de extratos aquosos de plantas invasoras não micorrízicas sobre o acúmulo de matéria seca e sobre a partição de assimilados de plantas de milho com inoculação ou não de Cetraspora pellucida. O experimento foi conduzido em vasos, em um delineamento inteiramente casualizado, com arranjo fatorial $5 \times 2$ que consistiu de quatro extratos vegetais (tiririca, guiné, caruru, erva-de-bicho), um controle irrigado com água e duas condições (plantas de milho micorrizadas e não micorrizadas), com quatro repetições de cada tratamento. As plantas foram irrigadas com extratos aquosos diluídos a 15\%. Avaliaram-se: a colonização radical (CR), a matéria seca da parte aérea (MSPA), a matéria seca das raízes (MSR) e MSR/MSPA. A colonização da raízes não foi influenciada pelos extratos, tendo variado de 41,5 a $65,2 \%$. A matéria seca da parte aérea das plantas micorrizadas (MA) e não micorrizadas (NM) não foi influenciada pelos extratos; no entanto, a MSR teve resposta diferenciada. A micorrização favoreceu a produção de MSR e aumentou a sensibilidade das plantas aos extratos. O extrato de guiné aumentou a MSR das plantas MA, e os outros extratos a inibiram. Em plantas NM, a MSR foi beneficiada pelo extrato de caruru, em detrimento da MSPA. Plantas de milho micorrizadas e não micorrizadas respondem diferentemente aos extratos aquosos de plantas invasoras não micorrizadas.
\end{abstract}

Termos para indexação: Zea mays, Amaranthus viridis, Cyperus rotundus, Petiveria alliacea, Polygonum ferrugineum, alelopatia.

\section{Introduction}

In agricultural areas, the presence of weedy plants is a problem that compromises production, as they compete for space and nutritional resources with cultivated plants, including maize (Cerrudo et al., 2012). In order to suppress competing species, weedy plants produce allelopathic substances, which are released into the soil and impair seed germination, radicle

Pesq. agropec. bras., Brasília, v.52, n.11, p.1042-1049, nov. 2017

DOI: 10.1590/S0100-204X2017001100010 
growth and, later, the roots, by various mechanisms (Cheng \& Cheng, 2015).

Among species with weedy potential, purple nutsedge (Cyperus rotundus L.) is the most harmful, as it is found in most environments, while slender amaranth (Amaranthus viridis L.) is common in soils rich in organic matter (Lorenzi, 2008). Guinea-hen weed (Petiveria alliaceae L.), a species considered medicinal in Brazil, can behave as a weed in pastures and arable areas (Rojas-Sandoval \& Acevedo-Rodríguez, 2014). Knotweed (Polygonum ferrugineum Wedd.) is not considered a weedy species and, like the three previously mentioned species, it belongs to a botanical family that is considered totally nonmycorrhizal, or with mycorrhizal and nonmycorrhizal species (Brundrett, 2009). If the allelopathic compounds produced by these plants negatively affect both symbionts (plant and mycorrhizal fungus), the presence of weeds could interfere with many other processes, which would destabilize the agroecosystem.

Negative responses associated with allelochemicals produced by guinea-hen weed and slender amaranth are common (Pérez-Leal et al., 2005; Tabrizi \& Yarnia, 2011). Purple nutsedge is a species with highallelopathic potential; several reports show its negative action on seed germination and initial growth of maize seedlings (Hamaiyn et al., 2005) and other Poaceae species, as well as on grain production (Silva et al., 2015). Although no reports were found with respect to knotweed, the family to which it belongs, Polygonaceae, is known to contain species that produce a number of biologically active compounds, such as emodin, a multi-action anthraquinone (Fan et al., 2009) frequently associated with inhibition of seedling growth by retarding the elongation of the root and the hypocotyl. In maize, Hasan (1998) found that the application from 10 to $100 \mathrm{mg} \mathrm{L}^{-1}$ emodin restricted the growth of roots and shoots. For metabolism, this retardation is related to the interruption of the respiratory process, and to the production of peptides and receptors that control cell division and differentiation in the radicular meristem (Dallali et al., 2014).

Root growth is more sensitive to the phytotoxic effects of allelopathic substances than the shoot system, even when they are in low concentrations in the soil (Ercoli et al., 2007; Wu et al., 2009). In addition to the direct influence on root growth, allelochemicals interfere with the physiological processes of plants, such as nutrient uptake and photosynthesis, which affects the regulation of arbuscular mycorrhizal symbiosis. Several allelopathic substances have a defense function against pathogens, such as fungi (Tapwal et al., 2011), without necessarily differentiating among functional and taxonomic groups.

Arbuscular mycorrhizal fungi (AMF) may have their growth and extra-radical development altered by the presence of these substances (Cantor et al., 2011), and if the effects are negative for the fungus, or for its efficiency in obtaining mineral nutrients, the growth of the host plant could be compromised. If damage occurs only to the plants, the establishment of a mycorrhizal association may bring benefits or losses to the plant, depending on the cost-benefit relationship (Smith \& Smith, 2015). If the associated fungi aid in the absorption of water and mineral nutrients, it will allow the plant to be more vigorous and tolerant to the negative action of the allelopathic substances. If, however, the fungi are not efficient, they will function as a drain for the plant, since the plant is already under an unfavorable condition. In addition, the increased absorbance of soil solution materials, including allelopathic substances (Achatz et al., 2014) promoted by the AMF, can intensify the action of these substances on the growth and development of a plant.

The damage caused by allelopathic substances, either at the beginning of crop development or in the vegetative phase (Silva et al., 2015), interferes with the production of grains, which can result in significant losses, especially if the weedy plant is resistant to herbicides (Webster \& Nichols, 2012). Determining whether the cause of these losses is due to the action of the allelochemicals on the plant, on the AMF, or on both, becomes relevant in an agronomic context.

The objective of this work was to evaluate the influence of aqueous extracts of nonmycorrhizal weeds on the accumulation of dry matter and assimilate partitioning between the shoot and radical systems of maize plants, with or without inoculation of the arbuscular mycorrhizal fungus Cetraspora pellucida.

\section{Materials and Methods}

The experiment was conducted in pots, in the greenhouse of the Departamento de Biologia of Universidade Estadual de Maringá, Maringá, PR, Brazil. The preparation of substances and laboratory

Pesq. agropec. bras., Brasília, v.52, n.11, p.1042-1049, nov. 2017 DOI: $10.1590 / \mathrm{S} 0100-204 \mathrm{X} 2017001100010$ 
analyses were carried out in the Laboratório de Sistemática de Fungos of the same department.

The soil used in the planting was an Oxisol, collected from horizon B on the campus of Universidade Estadual de Maringá. The soil was sieved and sterilized by autoclaving and, after chemical testing, its acidity was corrected with dolomitic limestone (PRNT 80\%). Fifteen days after liming, another sample was prepared, and six samples were subjected to analysis of chemical and physicochemical properties, according to the method described by IAC (2001). The extractor used for determining the $\mathrm{Ca}$ and $\mathrm{Mg}$ levels was $1 \mathrm{~mol} \mathrm{~L}^{-1} \mathrm{KCl}$; $\mathrm{pH}$ was measured in $\mathrm{CaCl}_{2} ; \mathrm{K}$ content was determined by Mehlich-1; and $\mathrm{P}$ content was determined by ion exchange resin. The evaluated properties were: $\mathrm{H}^{+}+\mathrm{Al}^{3+}, 2.1 \pm 0.15 \mathrm{cmol}_{\mathrm{c}} \mathrm{dm}^{-3} ; \mathrm{Ca}^{2+}, 2.7 \pm 0.13 \mathrm{cmol}_{\mathrm{c}} \mathrm{dm}^{-3}$; $\mathrm{Mg}^{2+}, 2.0 \pm 0.11 \mathrm{cmol}_{\mathrm{c}} \mathrm{dm}^{-3} ; \mathrm{K}^{+}, 0.05 \pm 0.03 \mathrm{cmol}_{\mathrm{c}} \mathrm{dm}^{-3}$; $\mathrm{P}_{\text {(res) }}, 2.6 \pm 0.81 \mathrm{mg} \mathrm{dm}^{-3} ; \mathrm{C}, 8.2 \pm 1.16 \mathrm{~g} \mathrm{dm}^{-3}$; and $\mathrm{pH}$ $\left(\mathrm{CaCl}_{2}\right), 6.2 \pm 0.05$.

The mycorrhizal inoculum was produced with soilinoculum, which contained spores and extraradical mycelium of the AMF Cetraspora pellucida (T.H. Nicolson \& N.C. Schenck) Oehl, F.A. Souza \& Sieverd., from the Coleção de Espécies de FMA of the Instituto Agronômico do Paraná. The inoculum was produced in sterilized soil pots by growing Cetraspora pellucida with Urochloa decumbens (Stapf.) Webster.

For aqueous extract preparation of the weedy plants, aerial parts of slender amaranth (Amaranthus viridis L., Amaranthaceae), purple nutsedge (Cyperus rotundus L., Cyperaceae), guinea-hen weed (Petiveria alliacea L.), and knotweed (Polygonum ferrugineum Wedd.) were collected early in the morning. The samples were superficially disinfected with 5\% sodium hypochlorite followed by three washes in distilled water. The plants were weighed in order to obtain $300 \mathrm{~g}$ of fresh material of each species, which was crushed in a blender with distilled water to make $1 \mathrm{~L}$ of solution. The liquid extract from each plant was then filtered through a $45 \mu \mathrm{m}$ mesh metal sieve, placed in an amber glass container, and stored under refrigeration.

Maize seed were planted in 40 pots of $2 \mathrm{~L}$ capacity, with $1.5 \mathrm{~L}$ of soil. In the treatments with AMF inoculum, $5 \mathrm{~g}$ of soil-inoculum containing spores of $C$. pellucida was added in the center of the pot, $5 \mathrm{~cm}$ below the surface. After the soil preparation, conventional maize seed (Zea mays L.) were sown. Thinning was done one week after the emergence of seedlings, in order to leave only one plant per pot. Prior to sowing, seed were washed in running water because they had been previously treated with fungicides by the manufacturer.

Maize plants irrigation was performed with the extracts diluted in distilled water at $15 \%$ concentration. Maize treatments was performed with $100 \mathrm{~mL}$ of the corresponding extract twice a week, whereas the controls received the same volume of deionized water. Once a week, all plants were irrigated with Hoagland nutrient solution at $0.02 \mathrm{~mL} \mathrm{P} \mathrm{L}^{-1}$ water and, as necessary, deionized water in equal quantities. Three months after seedling emergence, the aerial parts and total roots of plants, and $100 \mathrm{~g}$ of soil were collected from the pots of each treatment for the analyses of root dry matter (RDM), shoot dry matter (SDM), and the RDM/SDM ratio that determines the assimilate partitioning among the root and shoot systems, and the root colonization by the mycorrhizal fungi (RC). The roots were washed on a sieve, dried with paper towels, and weighed to determine the fresh matter mass; then, $1 \mathrm{~g}$ of roots was removed for evaluation of mycorrhizal colonization. The shoot systems were cleaned with a brush. Both roots and aerial parts were oven-dried at $65^{\circ} \mathrm{C}$, until a constant weight was obtained, in order to determine their respective dry matter mass.

To evaluate mycorrhizal colonization, roots were washed in running water and preserved in $70 \%$ alcohol. The samples were then subjected to clearing with $10 \% \mathrm{KOH}$, while being heated in a water bath for approximately two hours, and to acidification with $5 \% \mathrm{HCl}$, and to staining with Trypan blue according to the method of Phillips \& Hayman (1970). After staining, the quantification of radical colonization was performed by means of the gridline intersection method proposed by Giovannetti \& Mosse (1980).

Seedling growth was evaluated by comparing shoot dry matter to root dry matter. To compensate for the removal of the $1 \mathrm{~g}$ subsample of the roots, data were converted by rule of three, and RDM and RDM/SDM were estimated.

Data were initially tested for the assumptions of normality (Shapiro-Wilk), homogeneity (Levene) and linearity (visual inspection), and a two-factorial analysis of variance was performed, whose mean values for the treatments were compared using the Fisher test to detect of minimum significant differences. The 
level of significance was $5 \%$, and all analyses were done with Statistica software.

\section{Results and Discussion}

The aqueous extracts of the weeds altered the root dry matter (RDM), but not the shoot dry matter (SDM) in the two groups of plants, inoculated or not with Cetraspora pellucida (Table 1). Aerial and radical systems in which roots were more sensitive responded differently to the extracts; this fact has been previously observed by other authors (Ercoli et al., 2007; Wu et al., 2009). Assimilation partitioning between the radical and shoot systems (RDM/SDM) was influenced by the two factors investigated in the present study (mycorrhization and aqueous extract treatment). However, the response to extracts differed between mycorrhized (MA) and nonmycorrhized (NM) plants.

Inoculation of the control plants, which did not include extracts, favored the production of RDM and, although the higher RDM/SDM ratio showed a preferential allocation of resources to the roots, the production of SDM was not impaired (Table 1). Although mycorrhization favors lateral root production (Fusconi, 2014), the expected gains in SDM did not occur due to the higher volume of roots, and to the presence of the extraradical mycelium of the fungus inoculated in the formation, which can be explained by the uniformity of the potting conditions and the cost of mycorrhizal symbiosis (Smith \& Smith, 2015).

Mycorrhizal plants had an increased RDM when treated with the guinea-hen weed extract, but a decreased RDM with the extracts of purple nutsedge, slender amaranth, and knotweed; such responses were not observed in the NM plants (Table 1). The negative influence of the extracts of purple nutsedge and slender amaranth on maize root growth has also been reported in other studies (Hamayun et al., 2005; Tabrizi \& Yarnia, 2011). The shoot of guinea-hen weed accumulates a great quantity of allantoin (Sousa et al., 1990), a nitrogen-rich compound that plays an important role in the assimilation, metabolism, transport, and storage of $\mathrm{N}$ in plants (Smith \& Atckins, 2002). As allantoin is a derivative of inosine monophosphate, its concentration is directly related to the concentration of this purine, which has been reported to be a promoter of plant growth, especially of roots, as verified in rice, sunflower, and tomato (Tokuhisa et al., 2010).
Among the extracts that reduced the production of RDM in the AM plants, only knotweed affected RDM/ SDM, with a reduction of MSR/MSPA ratio (Table 1). The production of RDM increased in NM plants an it was only influenced by the slender amaranth extract, unlike that observed by Anaya et al. (1987), and Tabrizi \& Yarnia (2011). However, the beneficial effect of the slender amaranth extract on RDM of NM plants was associated with a lower investment in SDM formation. Allelopathic responses associated with the

Table 1. Means \pm standard deviations of shoot dry mass (SDM) and root dry mass (RDM) of mycorrhized (AM) and nonmycorrhized (NM) maize (Zea mays) plants treated with different aqueous extracts of nonmycorrhizal weedy plants (purple nutsedge, guinea henweed, slender amaranth, and knotweed) ${ }^{(1)}$.

\begin{tabular}{|c|c|c|c|c|}
\hline \multirow[t]{2}{*}{ Treatment } & \multirow{2}{*}{$\begin{array}{l}\text { Mycor- } \\
\text { rhization }\end{array}$} & \multirow[t]{2}{*}{ Extract } & \multicolumn{2}{|c|}{ Extract x mycorrhization } \\
\hline & & & $\mathrm{AM}$ & NM \\
\hline & \multicolumn{4}{|c|}{ Shoot dry mass (g) } \\
\hline $\mathrm{AM}$ & $0.67 \pm 0.13$ & - & - & - \\
\hline NM & $0.59 \pm 0.19$ & - & - & - \\
\hline Control & - & $0.71 \pm 0.15$ & $0.70 \pm 0.18$ & $0.72 \pm 0.15$ \\
\hline Purple & - & $0.56 \pm 0.23$ & $0.60 \pm 0.11$ & $0.52 \pm 0.33$ \\
\hline Guinea & - & $0.56 \pm 0.18$ & $0.67 \pm 0.12$ & $0.45 \pm 0.17$ \\
\hline Slender & - & $0.62 \pm 0.09$ & $0.57 \pm 0.05$ & $0.67 \pm 0.09$ \\
\hline Knotweed & - & $0.71 \pm 0.13$ & $0.82 \pm 0.05$ & $0.60 \pm 0.08$ \\
\hline \multirow[t]{2}{*}{ Fisher test } & $\mathrm{n}=16^{\mathrm{ns}}$ & $\mathrm{n}=8^{\mathrm{ns}}$ & \multicolumn{2}{|c|}{$\mathrm{n}=4^{\mathrm{ns}}$} \\
\hline & \multicolumn{4}{|c|}{ Root dry mass (g) } \\
\hline AM & $0.23 \pm 0.13 \mathrm{a}$ & - & - & - \\
\hline NM & $0.17 \pm 0.07 \mathrm{~b}$ & - & - & - \\
\hline Control & - & $0.20 \pm 0.09$ & $0.27 \pm 0.05 \mathrm{bA}$ & $0.12 \pm 0.05 \mathrm{bB}$ \\
\hline Purple & - & $0.16 \pm 0.10$ & $0.17 \pm 0.15 \mathrm{cA}$ & $0.15 \pm 0.06 \mathrm{bA}$ \\
\hline Guinea & - & $0.27 \pm 0.19$ & $0.42 \pm 0.15 \mathrm{aA}$ & $0.12 \pm 0.05 \mathrm{bB}$ \\
\hline Slender & - & $0.22 \pm 0.08$ & $0.15 \pm 0.05 \mathrm{cB}$ & $0.30 \pm 0.00 \mathrm{aA}$ \\
\hline Knotweed & - & $0.16 \pm 0.07$ & $0.15 \pm 0.10 \mathrm{cA}$ & $0.17 \pm 0.05 \mathrm{bA}$ \\
\hline \multirow[t]{2}{*}{ Fisher test } & $\mathrm{n}=16^{*}$ & $\mathrm{n}=8^{\mathrm{ns}}$ & \multicolumn{2}{|c|}{$\mathrm{n}=4 * * *$} \\
\hline & \multicolumn{4}{|c|}{ Root dry matter/ shoot dry matter ratio } \\
\hline AM & $0.36 \pm 0.23$ & - & - & - \\
\hline NM & $0.30 \pm 0.07$ & - & - & - \\
\hline Control & - & $0.29 \pm 0.17 b$ & $0.42 \pm 0.16 \mathrm{bA}$ & $0.17 \pm 0.06 \mathrm{bB}$ \\
\hline Purple & - & $0.29 \pm 0.14 b$ & $0.28 \pm 0.19 \mathrm{bA}$ & $0.31 \pm 0.08 \mathrm{bA}$ \\
\hline Guinea & - & $0.47 \pm 0.28 \mathrm{a}$ & $0.65 \pm 0.29 \mathrm{aA}$ & $0.28 \pm 0.04 \mathrm{bB}$ \\
\hline Slender & - & $0.35 \pm 0.12 \mathrm{ab}$ & $0.26 \pm 0.08 \mathrm{bB}$ & $0.45 \pm 0.06 \mathrm{aA}$ \\
\hline Knotweed & - & $0.23 \pm 0.11 \mathrm{~b}$ & $0.18 \pm 0.13 \mathrm{cA}$ & $0.29 \pm 0.06 \mathrm{bA}$ \\
\hline Fisher test & $\mathrm{n}=16^{\mathrm{ns}}$ & $\mathrm{n}=8 *$ & & \\
\hline
\end{tabular}

${ }^{(1)}$ Means following uppercase letters compare treatments in the rows (extract $\mathrm{x}$ mycorrhization) and lowercase letters in the columns.

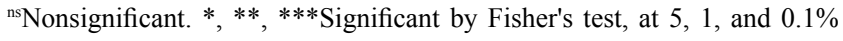
probability, respectively. 
use of aqueous extracts of Amaranthus retroflexus L. were also observed in plants of Lepidium sativum L. (Brassicaceae), a nonmycorrhizal species, which exhibited seedlings with a longer root and a greater quantity of total dry matter (shoot and root systems), when they were treated with stem or leaf extracts at 25 and 50\% concentrations (Mlakar et al., 2012).

In AM plants, decreases of the RDM production did not interfere in the development of the shoot system (Table 1), probably because of the benefits brought by mycorrhizae in the obtention of nutrients (Bagyaraj et al., 2015). Achatz et al. (2014) also observed decreases in the RDM formation without influence on shoot growth of mycorrhizal tomato plants treated with juglone, a quinone produced by Juglans regia L. (Hejl \& Koster, 2004).

Since the slender amaranth extract produced adverse effects on the production of RDM in AM and NM plants (Table 1), it can be inferred that the establishment of mycorrhizal symbiosis potentiated the negative influence of the allelochemicals due to their increased concentration in the roots. The works by Barto et al. (2011) and Achatz et al. (2014) showed that extraradical AMF hyphae absorb and transfer allelochemicals from the soil solution to the plants. The higher concentration of these compounds in the roots may have been responsible for the reduction of RDM in AM plants, as observed by Achatz et al. (2014).

Mycorrhization may have also altered plant responses to allelopathic compounds in the extracts, by promoting metabolic pathways related to detoxification, which resulted in an increased tolerance to allelochemicals. Although several studies have shown the positive influence of the arbuscular mycorrhizal association on plant tolerance to these compounds (Javaid, 2007), very little has been done to unravel the mechanisms involved in this process. Matsubara et al. (2010) associated the greater tolerance of mycorrhizal asparagus plants to allelochemicals with higher levels of ascorbic acid and polyphenols, which are two natural antioxidants.

In addition, it is possible that the allelochemicals present in the slender amaranth extract interfered in basic plant processes, such as hormonal balance and respiration, among others, and altered the growth of AM plants by direct or indirect mechanisms (Bogatek \& Gniazdowska, 2007; Ghayal et al., 2009), which include their interaction with the symbiotic fungus Cetraspora pellucida.

Maize and other species of Poaceae produce sesquiterpene lactones, such as strigolactones, which are released into the soil via radical exudation (Steinkellner et al., 2007). These are recognized as branching factors of AMF hyphae (Akiyama \& Hayashi, 2006). With the formation and subsequent growth of extraradical mycelium, it is expected that the mycobiont would require a greater amount of organic compounds for the synthesis of structural components, and for the maintenance of the metabolic activities of the hyphae (Finlay, 2008). This way, the plant no longer allocates energy to the formation of vegetable tissues, which is more costly, thus benefiting the AMF. Sesquiterpene lactones are produced by species of Amaranthaceae, such as Amaranthus spinosus L. (Suma et al., 2002), but no study to date has investigated the action of lactones, or any other compound produced by slender amaranth, on the development of AMF. Thus, it is not possible to affirm that the strigolactones present in the aqueous extract of Amaranthus viridis have influenced branching or growth of AMF hyphae.

In the present study, root colonization ranged from 41.5 to $65.2 \%$ (purple nutsedge and control, respectively) and it was not influenced by the extracts (Table 2). The roots were only colonized by arbuscules and hyphae (typical in Gigasporaceae), which shows that the pots were not contaminated with alloctone vesicle-forming fungi, such as those belonging to the genera Glomus

Table 2. Mean percentages of total root mycorrhizal colonization (TRC) and arbuscular colonization (AC) in maize plants inoculated with spores of Cetraspora pellucida, and treated with aqueous extracts of nonmycorrhizal weeds (purple nutsedge, guinea-hen weed, slender amaranth, and knotweed).

\begin{tabular}{lccccc}
\hline Treatment & \multicolumn{2}{c}{ TRC (\%) } & & \multicolumn{2}{c}{ AC (\%) } \\
\cline { 2 - 3 } \cline { 5 - 6 } & Mean & $\begin{array}{c}\text { Standard } \\
\text { deviation }\end{array}$ & & Mean & $\begin{array}{c}\text { Standard } \\
\text { deviation }\end{array}$ \\
\hline Water & 65.21 & 14.59 & & 64.67 & 14.96 \\
Purple nutsedge & 41.54 & 23.03 & & 40.91 & 24.06 \\
Guinea-hen weed & 55.34 & 4.16 & & 54.47 & 4.25 \\
Slender amaranth & 58.80 & 23.66 & & 55.11 & 19.81 \\
Knotweed & 52.72 & 5.71 & & 52.11 & 8.08 \\
\hline p-value & $0.382^{\text {ns }}$ & & & $0.380^{\text {ns }}$ \\
\hline
\end{tabular}

${ }^{\mathrm{n}}$ Nonsignificant. $\mathrm{n}=4$. 
and Acaulospora (sensu lato). The roots, for the most part, showed few intraradical hyphae, and were colonized by arbuscules only. The massive presence of arbuscules indicates intense activity of metabolite exchanges between the symbionts, since this occurs to a greater extent in arbuscules (Pumplin \& Harrison, 2009).

The responses reported in the production of RDM in AM plants may have resulted from the direct influence of the allelochemicals on the extraradical mycelium, as mycorrhizal colonization was not affected by the extracts. Negative action of allelopathic substances on AMF is scarce, and it is generally associated with the presence of glucosinolates, which are common compounds in species of Brassicaceae (Bainard et al., 2009).

In the present study, the extraradical mycelium of Cetraspora pellucida may have increased the uptake of the allelopathic compounds present in the soil solution, and caused the lower RDM formation of the AM plants (Table 1); apparently, they were neither transferred to the aerial parts nor transferred at low nonphytotoxic concentrations, as observed in the association of Rhizophagus irregularis-tomato (Achatz et al., 2014). This reduction may be due to the sequestration of these compounds in the walls of the hyphae (phytoextraction), which would prevent their distribution to the rest of the plant. Glomalin, a glycoprotein present in the wall of arbuscular mycorrhizal fungi, has been reported as active in the sequestration of heavy metals present in the soil (Vodnik et al., 2008). In the present study, the accumulation of allelochemicals in the absorption system (roots and hyphae) may explain the fact that there was no influence of the extracts on dry matter production in the AM maize plants. However, studies aimed at extracting, identifying, and quantifying the active compounds accumulated in the roots and the extraradical mycelium are necessary to confirm such hypotheses.

\section{Conclusions}

1. The aqueous extracts of the evaluated weeds do not influence the dry matter production of the aerial parts of maize plants, irrespective of their mycorrhizal condition.

2. The extracts of purple nutsedge, slender amaranth, and knotweed, reduce the dry matter production of roots of mycorrhizal maize plants, while the extract of guinea knotweed increases it.

3. The extract of slender amaranth favors the partitioning of nutrient resources for the production of roots in nonmycorrhizal maize plants to the detriment of maize aerial parts.

4. The extracts of the evaluated weedy plants do not influence the colonization of the roots by Cetraspora pellucida.

5. Maize plants respond differently to the extracts of weedy plants, regardless of the mycorrhizal situation.

\section{Acknowledgments}

To Coordenação de Aperfeiçoamento de Pessoal de Nível Superior (Capes), for the scholarship granted to the first author; and to Mr. Benício Alves de Abreu Filho, of the Departamento de Análises Clínicas e Biomedicina, of Universidade Estadual de Maringá (UEM), who collaborated in the preparation of the extracts.

\section{References}

ACHATZ, M.; MORRIS, E.K.; MÜLLER, F.; HILKER, M.; RILLIG, M.C. Soil hypha-mediated movement of allelochemicals: arbuscular mycorrhizae extend the bioactive zone of juglone. Functional Ecology, v.28, p.1020-1029, 2014. DOI: 10.1111/13652435.12208.

AKIYAMA, K.; HAYASHI, H. Strigolactones: chemical signals for fungal symbionts and parasitic weeds in plant roots. Annals of Botany, v.97, p.925-931, 2006. DOI: 10.1093/aob/mcl063.

ANAYA, A.L.; RAMOS, L.; CRUZ, R.; HERNÁNDEZ, J.G.; NAVA,V. Perspectives on allelopathy in Mexican traditional agroecosystems: a case study in Tlaxcala. Journal of Chemical Ecology, v.13, p.2083-2101, 1987. DOI: 10.1007/BF01012873.

BAGYARAJ, D.J.; SHARMA, M.P.; MAITI, D. Phosphorus nutrition of crops through arbuscular mycorrhizal fungi. Current Science, v.108, p.1288-1293, 2015.

BAINARD, L.D.; BROWN, P.D.; UPADHYAYA, M.K. Inhibitory effect of tall hedge mustard (Sisymbrium loeselii) allelochemicals on rangeland plants and arbuscular mycorrhizal fungi. Weed Science, v.57, p.386-393, 2009. DOI: 10.1614/WS-08-151.1.

BARTO, E.K.; HILKER, M.; MÜLLER, F.; MOHNEY, B.K.; WEIDENHAMER, J.D.; RILLIG, M.C. The fungal fast lane: common mycorrhizal networks extend bioactive zones of allelochemicals in soils. PLoS ONE, v.6, e27195, 2011. DOI: 10.1371/journal.pone.0027195.

BOGATEK, R.; GNIAZDOWSKA, A. ROS and phytohormones in plant-plant allelopathic interaction. Plant Signaling and Behavior, v.2, p.317-318, 2007. DOI: 10.4161/psb.2.4.4116. 
BRUNDRETT, M. Mycorrhizal associations and other means of nutrition of vascular plants: understanding the global diversity of host plants by resolving conflicting information and developing reliable means of diagnosis. Plant and Soil, v.320, p.37-77, 2009. DOI: $10.1007 / \mathrm{s} 11104-008-9877-9$.

CANTOR, A.; HALE, A.; AARON, J.; TRAW, M.B.; KALISZ, $\mathrm{S}$. Low allelochemical concentrations detected in garlic mustardinvaded forest soils inhibit fungal growth and AMF spore germination. Biological Invasions, v.13, p.3015-3025, 2011. DOI: 10.1007/s10530-011-9986-x.

CERRUDO, D.; PAGE, E.R.; TOLLENAAR, M.; STEWART, G.; SWANTON, C.J. Mechanisms of yield loss in maize caused by weed competition. Weed Science, v.60, p.225-232, 2012. DOI: 10.1614/WS-D-11-00127.1.

CHENG, F.; CHENG, Z. Research progress on the use of plant allelopathy in agriculture and the physiological and ecological mechanisms of allelopathy. Frontiers in Plant Science, v.6, art.1020, 2015. DOI: 10.3389/fpls.2015.01020.

DALLALI, S.; LAHMAYER, I.; MOKNI, R.; MARICHALI, A.; OUERGHEMMI, S.; BEL HADJ LTAIEF, H.; SEBEI, H. Phytotoxic effects of volatile oil from Verbena spp. on the germination and radicle growth of wheat, maize, linseed and canary grass and phenolic content of aerial parts. Allelopathy Journal, v.34, p.95-106, 2014.

ERCOLI, L.; MASONI, A.; PAMPANA, S.; ARDUINI, I. Allelopathic effects of rye, brown mustard and hairy vetch on redroot pigweed, common lambsquarter and knotweed. Allelopathy Journal, v.19, p.249-256, 2007.

FAN,P.; HAY, A.-E.; MARSTON, A.;LOU,H.; HOSTETTMANN, K. Chemical variability of the invasive neophytes Polygonum cuspidatum Sieb. and Zucc. and Polygonum sachalinensis F. Schmidt ex Maxim. Biochemical Systematics and Ecology, v.37, p.24-34, 2009. DOI: 10.1016/j.bse.2008.11.018.

FINLAY, R.D. Ecological aspects of mycorrhizal symbiosis: with special emphasis on the functional diversity of interactions involving the extraradical mycelium. Journal of Experimental Botany, v.59, p.1115-1126, 2008. DOI: 10.1093/jxb/ern059.

FUSCONI, A. Regulation of root morphogenesis in arbuscular mycorrhizae: what role do fungal exudates, phosphate, sugars and hormones play in lateral root formation? Annals of Botany, v.113, p.19-33, 2014. DOI: 10.1093/aob/mct258.

GHAYAL, N.; DHUMAL, K.; GUPTA, S.; PHADKE, M.; PARANGE, S. Morphophysiological investigations in some dominant alien invasive weeds. Journal of Plant Interactions, v.4, p.33-39, 2009. DOI: 10.1080/17429140802385964.

GIOVANNETTI, M.; MOSSE, B. An evaluation of techniques for measuring vesicular-arbuscular mycorrhizal infection in roots. New Phytologist, v.84, p.489-500, 1980. DOI: 10.1111/j.14698137.1980.tb04556.x.

HAMAYUN, M.; HUSSAIN, F.; AFZAL, S.; AHMAD, N. Allelopathic effect of Cyperus rotundus and Echinochloa crusgalli on seed germination, and plumule and radicle growth in maize (Zea mays L.). Pakistan Journal of Weed Science Research, v.11, p.81-84, 2005.
HASAN, H.A.H. Studies on toxigenic fungi in roasted foodstuff (salted seed) and halotolerant activity of emodin-producing Aspergillus wentii. Folia Microbiologica, v.43, p.383-391, 1998. DOI: $10.1007 / \mathrm{BF} 02818578$.

HEJL, A.M.; KOSTER, K.L. Juglone disrupts root plasma membrane H+-ATPase activity and impairs water uptake, root respiration, and growth in soybean (Glycine max) and corn (Zea mays). Journal of Chemical Ecology, v.30, p.453-471, 2004. DOI: 10.1023/B:JOEC.0000017988.20530.d5.

IAC. Instituto Agronômico de Campinas. Manual de análise química para avaliação de fertilidade de solos tropicais. Campinas: Instituto Agronômico, 2001. 285p.

JAVAID, A. Allelopathic interactions in mycorrhizal associations. Allelopathy Journal, v.20, p.29-42, 2007.

LORENZI, H. Plantas daninhas do Brasil: terrestres, aquáticas, parasitas e tóxicas. 4.ed. Nova Odessa: Instituto Plantarum, 2008. $640 \mathrm{p}$.

MATSUBARA, Y.; OKADA, T.; NAHIYAN, A.S.M. Tolerance to allelopathy and Fusarium disease, changes in antioxidative substances in mycorrhizal asparagus plants raised in decline soil. Acta Horticulturae, v.883, p.417-423, 2010. DOI: 10.17660/ ActaHortic.2010.883.52.

MLAKAR, S.G.; JAKOP, M.; BAVEC, M.; BAVEC, F. Allelopathic effects of Amaranthus retroflexus and Amaranthus cruentus extracts on germination of garden cress. African Journal of Agricultural Research, v.7, p.1492-1497, 2012. DOI: 10.5897/AJAR11.1145.

PÉREZ-LEAL， R.; GARCÍA-MATEOS，M.R.; VÁSQUEZROJAS, T.R.; COLINAS-LEÓN, M.T. Allelopathic potential of Petiveria alliacea L. Agronomy for Sustainable Development, v.25, p.177-182, 2005. DOI: 10.1051/agro:2005015.

PHILLIPS, J.M.; HAYMAN, D.S. Improved procedures for clearing roots and staining parasitic and vesicular-arbuscular mycorrhizal fungi for rapid assessment of infection. Transactions of the British Mycological Society, v.55, p.158-161, 1970. DOI: 10.1016/S0007-1536(70)80110-3.

PUMPLIN, N.; HARRISON, M.J. Live-cell imaging reveals periarbuscular membrane domains and organelle location in Medicago truncatula roots during arbuscular mycorrhizal symbiosis. Plant Physiology, v.151, p.809-819, 2009. DOI: 10.1104/pp.109.141879.

ROJAS-SANDOVAL, J.; ACEVEDO-RODRÍGUEZ, P. Petiveria alliacea (guinea hen weed). In: CABI. Invasive Species Compendium. 2014. Available at: <http://www.cabi.org/isc/ datasheet/70236>. Accessed on: Apr. 172017.

SILVA, D.V.; FREITAS, M.A.M. de; SILVA, G.S. da; SOUZA, M. de F.; SILVA, A.A. da; FERREIRA, L.R.; SEDIYAMA, T.; CECON, P.R. Crescimento e rendimento do milho sob interferência da tiririca. Semina: Ciências Agrárias, v.36, p.3077-3084, 2015. DOI: $10.5433 / 1679-0359.2015 v 36 n 5 p 3077$.

SMITH, F.A.; SMITH, S.E. How harmonious are arbuscular mycorrhizal symbioses? Inconsistent concepts reflect different mindsets as well as results. New Phytologist, v.205, p.1381-1384, 2015. DOI: 10.1111/nph.13202. 
SMITH, P.M.C.; ATKINS, C.A. Purine biosynthesis: big in cell division, even bigger in nitrogen assimilation. Plant Physiology, v.128, p.793-802, 2002. DOI: 10.1104/pp.010912.

SOUSA, J.R. de; DEMUNER, A.J.; PINHEIRO, J.A.; BREITMAIER, E.; CASSELS, B.K. Dibenzyl trisulphide and trans-N-methyl-4-methoxyproline from Petiveria alliacea. Phytochemistry, v.29, p.3653-3655, 1990. DOI: 10.1016/0031-9422(90)85294-P.

STEINKELLNER， S.; LENDZEMO, V.; LANGER， I.; SCHWEIGER, P.; KHAOSAAD, T.; TOUSSAINT, J.P.; VIERHEILIG, H. Flavonoids and strigolactones in root exudates as signals in symbiotic and pathogenic plant-fungus interactions. Molecules, v.12, p.1290-1306, 2007. DOI: 10.3390/12071290.

SUMA, S.; AMBIKA, S.R.; KAZINCZI, G.; NARWAL, S.S. Allelopathic plants 6. Amaranthus spp. Allelopathy Journal, v.10, p.1-11, 2002.

TABRIZI, E.F.M.; YARNIA, M. Allelopathy extracts various parts of pigweed germination and seedling growth corn. Annals of Biological Research, v.2, p.83-86, 2011.
TAPWAL, A.; NISHA, GARG, S.; GAUTAM, N.; KUMAR, R. In vitro antifungal potency of plant extracts against five phytopathogens. Brazilian Archives of Biology and Technology, v.54, p.1093-1098, 2011. DOI: 10.1590/S1516-89132011000600003.

TOKUHISA, D.; SHINANO, T.; WATANABE, T.; YAMAMURA, T.; OSAKI, M. Promotion of root growth by the application of inosine. Soil Science and Plant Nutrition, v.56, p.272-280, 2010. DOI: 10.1111/j.1747-0765.2010.00452.x.

VODNIK, D.; GRČMAN, H.; MAČEK, I.; VAN ELTEREN, J. T.; KOVAČENIČ, M. The contribution of glomalin-related soil protein to $\mathrm{Pb}$ and $\mathrm{Zn}$ sequestration in polluted soil. Science of the Total Environment, v.392, p.130-136, 2008. DOI: 10.1016/j. scitotenv.2007.11.016.

WEBSTER, T.M.; NICHOLS, R.L. Changes in the prevalence of weed species in the major agronomic crops of the Southern United States: $1994 / 1995$ to 2008/2009. Weed Science, v.60, p.145-157, 2012. DOI: 10.1614/WS-D-11-00092.1.

WU, A.-P.; YU, H.; GAO, S.-Q.; HUANG, Z.-Y.; HE, W.-M.; MIAO, S.-L.; DONG, M. Differential belowground allelopathic effects of leaf and root of Mikania micrantha. Trees, v.23, p.11-17, 2009.

Received on August 26, 2016 and accepted on April 13, 2017 